\title{
PENGARUH METODE PENGGORENGAN DAN KONSENTRASI JAMUR TIRAM PUTIH (Pleurotus streatus) TERHADAP KARAKTERISTIK KIMIA DAN MIKROBIOLOGI ABON UDANG (Panaeus indicus)
}

\section{THE INFLUENCE OF FRYING METHODE AND (Pleurotus ostreatus) CONCENTRATION ON CHEMICAL AND MICROBIOLOGICAL PROPERTIES OF SHRIMPS SHREDDED (Panaeus indicus)}

\author{
Arba Susanty, Paluphy Eka Yustini, Sitti Nurlina \\ Balai Riset dan Standardisasi Industri Samarinda \\ Jl. Banggeris No.1, Samarinda 75124 \\ Email: arba@kemenperin.go.id
}

\begin{abstract}
ABSTRAK
Udang merupakan sumber pangan hewani yang kaya akan protein. Jenis udang Panaeus indicus dapat diolah menjadi produk abon. Proses penggorengan merupakan tahapan penting untuk menghasilkan produk abon. Proses pengorengan menghasilkan produk dengan aroma dan rasa makanan yang khas. Pemanasan mengakibatkan terjadinya denaturasi dan koagulasi protein yang berpengaruh terhadap tekstur abon. Untuk mengurangi kenampakan tekstur menggumpal dilakukan penambahan jamur tiram putih (Pleurotus ostreatus). Penelitian ini bertujuan untuk mengetahui pengaruh metode penggorengan dan konsentrasi bahan pengisi jamur tiram putih yang berbeda terhadap karakteristik kimia dan mikrobiologi abon udang Panaeus indicus. Penelitian ini menggunakan rancangan acak lengkap 2 faktor yaitu metode penggorengan terdiri dari pan frying dan deep frying dan konsentrasi jamur tiram putih terdiri dari $15 \%$, 30\% dan $45 \%$. Hasil penelitian ini menunjukkan metode penggorengan memberikan pengaruh nyata terhadap kadar abu, protein dan kadar lemak, sedangkan konsentrasi jamur tiram putih (Pleurotus ostreatus) yang berbeda berpengaruh nyata pada kadar air dan kadar serat abon udang Panaeus indicus. Abon udang Panaeus indicus memiliki kadar air 31,59-46,9\%, kadar abu 4,55 $7,92 \%$, kadar protein 12,51 - 24,29\%, kadar lemak 3,3-14,03\%, serat kasar 4,53-12,83\%, Salmonella negatif dan angka lempeng total $5,97 \times 10^{2}-3,98 \times 10^{4} \mathrm{koloni} / \mathrm{gram}$.
\end{abstract}

Kata Kunci: abon, Panaeus indicus, Pleurotus ostreatus, pan frying, deep frying

\begin{abstract}
The shrimp (Panaeus indicus) is a source of protein and can be further processed to shredded shrimp. The frying process is an important step to produce shredded shrimp. Frying process produces a food with a distinctive flavour and taste. Heating results in the denaturation and coagulation of proteins that effect on texture. To reduce the appearance of this clumpy texture, the addition of Pleurotus streatus is carried out. This study aims to determine the effect of the frying method and concentration of Pleurotus ostreatus on chemical and microbiological properties of shredded shrimp Panaeus indicus. This research used completely randomized design with two factors frying methode and Pleurotus ostreatus concentration from 15\%, 30\% and 45\%. The results of this study show frying methode effect on ash value, protein and fat value. Concentartion of Pleurotus streatus had effect on moisture and crude fiber of shredded shrimp Panaeus indicus. The properties of shredded shrimp Panaeus indicus had moisture content of $31,59-46,9 \%$, ash content of $4,55-7,92 \%$, protein content of 12,51 $24,29 \%$, fat content of $3,3-14,03 \%$, crude fiberr content of $4,53-12,83 \%$, negative for Salmonella

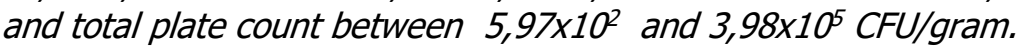

Keywords: shredded, Panaeus indicus, Pleurotus streatus, frying

80 Arba Susanty, Paluphy Eka Yustini, Sitti Nurlina Pengaruh Metode Penggorengan dan Konsentrasi Jamur Tiram Putih (Pleurotus Streatus) Terhadap Karakteristik Kimia dan Mikrobiologi Abon Udang (Panaeus Indicus) 


\section{PENDAHULUAN}

M enurut SNI 01-3707-1995, abon adalah suatu jenis makanan kering berbentuk khas, dibuat dari daging, direbus disayat-sayat, dibumbui, digoreng dan dipres. Merupakan salah satu jenis makanan awetan berasal dari daging sapi, kerbau, ataupun ikan laut. Abon diolah sedemikian rupa sehingga memiliki karakteristik kering, renyah dan gurih. Bahan utama dalam pembuatan abon biasanya menggunakan daging sapi, kerbau, ayam atau ikan. Salah satu komoditi perikanan yang dapat dikembangkan menjadi produk abon berasal dari jenis krustase yaitu jenis udang putih (Panaeus indicus).

Abon ikan merupakan produk kering dimana penggorengan merupakan salah satu tahap yang dilakukan dalam pengolahannya (Suryani, 2007). Metode penggorengan merupakan proses pemanasan produk dengan suhu tinggi dan medium minyak goreng sebagai penghantar panas. Menurut Ketaren (1986), sistem menggoreng bahan pangan ada dua macam yaitu deep frying dimana bahan yang digoreng terendam seluruhnya dalam minyak dan pan frying yaitu proses penggorengan yang hanya menggunakan sedikit minyak. Metode penggorengan menggunakan minyak merupakan metode yang ekonomis, cepat, dan dapat membuat rasa makanan lebih spesifik. Selama proses penggorengan akan terjadi reaksi maillard yang memberikan aroma dan rasa yang khas pada bahan pangan (Zhang et al., 2012).

Penambahan bahan pengisi pada produksi abon sering dilakukan oleh industri. Penambahan bahan nabati yang mempunyai serat ini selain meningkatkan volume produk abon, dapat pula meningkatkan kandungan gizi dari abon tersebut. Menurut Fachruddin (1997) penambahan bahan campuran $20-30 \%$ pada abon umumnya masih disukai oleh konsumen, sedangkan Dewi (2011) menyatakan sifat organoleptik abon ikan substitusi jantung pisang sebanyak $40 \%, 50 \%$, dan $60 \%$ menunjukkan adanya perbedaan yang signifikan terhadap tekstur, rasa aroma, dan warna abon ikan. Tato, dkk (2014) melaporkan penambahan jamur tiram putih sebanyak $25 \%$ memberikan hasil yang terbaik pada abon ikan nila.

Jamur tiram putih (Pleurotus ostreatus) merupakan jenis jamur kayu yang banyak dibudidayakan dan memiliki kandungan nutrisi yang lebih tinggi, dibandingkan jenis jamur kayu lainnya. Jamur tiram putih dapat digunakan untuk makanan diet karena kandungan lemak yang rendah akan tetapi memiliki kandungan protein tinggi (Jamilah, 2016). Jamur tiram putih memiliki cita rasa dan tekstur yang spesifik. Susanty (2016) menyebutkan jenis bahan pengisi yang berbeda berpengaruh terhadap kandungan protein dan serat abon udang, dimana penambahan jamur tiram putih menghasilkan abon udang dengan kandungan nutrisi yang paling baik. Informasi mengenai pengaruh metode penggorengan dan konsentrasi bahan pengisi terhadap kandungan gizi abon udang belum diketahui oleh karena itu penelitian ini dilakukan untuk mengetahui pengaruh metode penggorengan dan konsentrasi bahan pengisi jamur tiram putih yang berbeda terhadap kadar air, kadar abu, kadar protein, kadar lemak, serat dan mikrobiologi abon udang Panaeus indicus.

\section{METODE PENELITIAN}

Bahan-bahan utama yang digunakan dalam penelitian ini adalah udang jenis Paneus indicus yang diperoleh dari daerah petambakan di Kecamatan Anggana Kabupaten Kutai Kartanegara. Bahan pengisi berupa jamur tiram putih dan bumbu rempah diperoleh dari kota Samarinda. Bahan kimia analisa meliputi $\mathrm{H}_{2} \mathrm{SO}_{4}, \mathrm{NaOH}$, tiosulfat, indikator pp, indicator amylum, $\mathrm{HCl}, \mathrm{KI}, \mathrm{KIO}_{2}$, Bismuth sulfit agar (BSA), Briliant green agar (BGA), pereaksi galaktosidase, pereaksi indol, nutrient agar (Merck)

Alat untuk pembuatan abon antara lain pisau, penggiling daging (chopper), peniris (spinner), kompor, timbangan digital (Tanita) dan blender (Philips). Sedangkan alat untuk 
analisa sampel antara lain spektrofotometer UV-VIS, electric muffle furnace, timbangan analitik, oven, satu set alat Kjeldahl (kjeldatherm), desikator dan peralatan gelas.

Penelitian ini menggunakan metode eksperimen. Menurut Nazir (2005) penelitian eksperimental adalah penelitian yang dilakukan dengan mengadakan manipulasi terhadap objek penelitian. Faktor yang diamati dalam penelitian ini terdiri dari dua faktor. Faktor pertama adalah metode pengorengan yaitu deep frying dan pan frying. Faktor kedua adalah konsentrasi bahan pengisi jamur tiram yaitu 15\%, 30\% dan $45 \%$. Semua perlakuan diulang sebanyak 3 kali.

Proses pengolahan abon udang dilakukan dengan tahapan preparasi bahan utama terlebih dahulu. Udang dibersihkan dari kulit dan kepalanya, dicuci bersih kemudian dipanaskan sampai sebagian besar air keluar dan kering dengan cara penyangraian. Udang kemudian dihaluskan menggunakan alat penghancur daging. Selanjutnya disimpan pada suhu dingin. Untuk bahan pengisi jamur tiram putih dilakukan tahapan pencucian dan pengukusan selama 15 menit. Selanjutnya kadar air jamur tiram dikurangi menggunakan spinner dan kemudian jamur tiram putih dihaluskan menggunakan alat penghancur daging. Pembuatan abon udang dilakukan dengan melakukan pencampuran bumbu dengan udang dan bahan pengisi sesuai perlakuan. Selanjutnya dilakukan proses penggorengan dengan dua metode. Pada metode pan frying proses penggorengan dilakukan dengan menambahkan minyak goreng sebanyak $15 \mathrm{ml}$ pada campuran udang, jamur tiram putih dan bumbu yang hampir kering sehingga tidak menempel pada penggorengan selama 60 menit. Sedangkan pada metode deep frying campuran udang, jamur tiram putih dan bumbu yang telah merata, digoreng dalam minyak kelapa sawit panas sampai abon berwarna kuning kecoklatan dengan lama waktu pengorengan selama 15 menit. Selanjutnya dilakukan proses pengurangan kandungan minyak menggunakan alat spinner.

Parameter yang diamati meliputi kadar air, kadar abu, lemak, protein dan serat kasar mengacu pada metode Sudarmadji dkk (1997) dan uji cemaran mikroba yaitu angka lempeng total dan Salmonella mengacu pada metode SNI 01-2332.2006.

Data yang diperoleh ditabulasikan dan dianalisis sesuai dengan rancangan yang telah ditentukan menggunakan Analysis of Variance (ANOVA) dan apabila terdapat perbedaan yang nyata dilajutkan dengan uji DMRT pada taraf kepercayaan 95\%, menggunakan program SPSS versi 20.

\section{HASIL DAN PEMBAHASAN}

Hasil analisis kimia beberapa parameter kualitas sesuai standard mutu abon SNI 013707-1995, disajikan pada Tabel 1.

Tabel 1. Rerata nilai karakteristik kimia abon udang (Panaeus indicus) dengan konsentrasi jamur tiram dan metode pengorengan yang berbeda

\begin{tabular}{|c|c|c|c|c|c|c|}
\hline \multicolumn{2}{|c|}{ Perlakuan } & \multirow{2}{*}{$\begin{array}{l}\text { Kadar Air } \\
\text { (\%) }\end{array}$} & \multirow{2}{*}{ Kadar Abu (\%) } & \multirow{2}{*}{ Lemak (\%) } & \multirow{2}{*}{$\begin{array}{l}\text { Protein } \\
\text { (\%) }\end{array}$} & \multirow{2}{*}{$\begin{array}{c}\text { Serat Kasar } \\
(\%)\end{array}$} \\
\hline $\begin{array}{c}\text { Metode } \\
\text { Penggorengan }\end{array}$ & $\begin{array}{l}\text { Konsentrasi } \\
\text { Jamur Tiram }\end{array}$ & & & & & \\
\hline \multirow{3}{*}{ Pan Frying } & $15 \%$ & $46,9 \pm 3,10^{b}$ & $4,55 \pm 0,78^{a}$ & $3,3 \pm 2,00^{a}$ & $23,46 \pm 0,04^{a}$ & $4,53 \pm 1,16^{a}$ \\
\hline & $30 \%$ & $44,54 \pm 6,29 a b$ & $5,25 \pm 1,01^{a b}$ & $6,1 \pm 1,04^{a}$ & $20,36 \pm 1,74^{a}$ & $8,65 \pm 3,16^{a}$ \\
\hline & $45 \%$ & $33,86 \pm 1,46^{a}$ & $5,95 \pm 1,11^{b}$ & $7,4 \pm 1,65^{a}$ & $24,29 \pm 2,45^{a}$ & $8,53 \pm 0,96^{a}$ \\
\hline \multirow{3}{*}{ Deep Frying } & $15 \%$ & $41,81 \pm 4,27^{b}$ & $6,49 \pm 0,26^{a}$ & $13,23 \pm 2,77^{a}$ & $16,76 \pm 1,00$ a & $8,93 \pm 1,50^{a}$ \\
\hline & $30 \%$ & $36,9 \pm 4,85^{a b}$ & $7,23 \pm 0,61^{a b}$ & $14,03 \pm 4,99^{a}$ & $17,98 \pm 3,22^{a}$ & $9,7 \pm 2,46^{a}$ \\
\hline & $45 \%$ & $31,59 \pm 5,03^{a}$ & $7,92 \pm 0,56^{b}$ & $13,09 \pm 0,9^{a}$ & $12,51 \pm 1,07^{a}$ & $12,83 \pm 3,8^{a}$ \\
\hline \multicolumn{2}{|c|}{ SNI 01-3707-1995 } & Maks. 7 & Maks.7 & Maks. 30 & Min. 15 & Mak. 1,04 \\
\hline
\end{tabular}

Keterangan:

- Angka yang tertera merupakan rata-rata dari tiga ulangan perlakuan dan standard deviasi

- Superskrip yang sama pada kolom yang sama menunjukkan tidak beda nyata ( $p>5 \%)$ 


\section{Kadar Air}

Air merupakan komponen penting dalam bahan pangan. Air dapat mempengaruhi penampakan, tekstur dan cita rasa makanan. Kadar air dalam bahan makanan berperan menentukan kesegaran dan daya awet bahan makanan (Winarno, 2002). Kadar air juga menentukan daya awet makanan, karena faktor ini mempengaruhi sifat-sifat fisik (kekerasan dan kekeringan) dan sifat fisiko kimia, perubahan kimia (pencoklatan enzimatis), kerusakan mikrobiologis dan perubahan enzimatis (Buckle, 2009).

Abon udang memiliki kadar air antara 31,59 - 46,9\%. Hasil analisis sidik ragam menunjukkan kosentrasi jamur tiram berpengaruh nyata terhadap kadar air abon udang. Pada Tabel 1 dapat dilihat semakin tinggi konsentrasi jamur tiram maka kadar air semakin rendah, hal ini terjadi pada kedua metode penggorengan abon udang. Akan tetapi pada metode deep frying, kadar air abon udang lebih rendah dibandingkan metode pan frying. Pada metode deep frying bahan abon udang terendam seluruhnya dalam minyak, mengakibatkan air lebih banyak keluar dari bahan. Hal ini sesuai dengan hasil penelitian Dewi, dkk (2012) yang menyatakan kadar air abon ikan tongkol (Euthynnus affinis Cantor) menggunakan metode deep frying $(4,098 \%)$ lebih rendah dari metode pan prying (6,258\%). Fennema (2004) menyatakan selama proses penggorengan, air akan keluar dari bahan menuju minyak yang panas. Pada konsentrasi jamur tiram putih $45 \%$, menghasilkan abon udang dengan kadar air yang paling rendah yaitu $31,59 \%$ dan 33,86\%. Hal ini dapat disebabkan karena komposisi jamur tiram yang hampir sama dengan udang Panaeus indicus dan karakteristik jamur tiram putih yang telah berkurang kadar airnya melalui proses pengukusan dan pengepresan sebelum pencampuran dengan udang. Pada metode deep frying, banyaknya minyak goreng yang dipakai pada saat penggorengan dengan suhu tinggi, menghasilkan penyebaran panas yang terjadi lebih cepat sehingga terjadi penguapan sejumlah air dalam bahan pangan yang digantikan oleh minyak.

Kadar air abon udang Panaeus indicus berada diatas persyaratan standar mutu abon yaitu maksimal 7\%. Masih tingginya kadar air abon udang ini dapat disebabkan oleh tingginya kadar air pada bahan baku segar. Jamur tiram putih segar memiliki kandungan air 91,8\% (Widyastuti, 2015), sedangkan udang jenis Panaeus indicus memiliki kadar air 76,14\% (Novrihansa, 2018). Walaupun pada proses pengolahan dilakukan proses pengurangan kadar air dengan melakukan proses penyangraian pada udang serta pengukusan dan pengepresan pada jamur tiram putih, akan tetapi belum dapat menghasilkan abon udang dengan kadar air yang dipersyaratkan. Selain itu waktu yang diperlukan pada proses penggorengan juga berpengaruh terhadap kadar air. Semakin lama waktu penggorengan akan menghasilkan abon dengan kadar air rendah, akan tetapi dari tekstur abon yang dihasilkan menjadi sangat keras. Pada penelitian ini waktu yang diperlukan untuk proses penggorengan ditentukan berdasarkan kondisi tekstur abon yang layak untuk dikonsumsi. Akan tetapi masih menghasilkan abon dengan kadar air abon yang berada diatas standar mutu.

\section{Kadar Abu}

Abu merupakan zat organik sisa hasil pembakaran suatu bahan organik, Kadar abu ada hubungannya dengan mineral suatu bahan. Mineral suatu bahan merupakan garam organik (garam-garam malat, oksalat, asetat, pektat) dan garam-garam anorganik (garam fosfat, karbonat, klorida, sulfat dan nitrat) (Fenemma, 2004).

Hasil uji kadar abu abon udang berkisar antara 4,55\% sampai dengan 7,92\%. Hasil analisis sidik ragam menunjukkan konsentrasi jamur tiram dan metode penggorengan berpengaruh nyata terhadap kadar abu abon udang Panaeus indicus. Pada Tabel 1 dapat diketahui kadar abu abon udang yang diproses dengan metode pan frying memiliki kadar abu lebih rendah dibandingkan metode deep frying. Semakin tinggi konsentrasi jamur tiram kadar 
abu abon udang semakin meningkat pula. Pada metode deep frying penggunaan minyak goreng yang merendam bahan abon pada proses penggorengan mengakibatkan air pada bahan menguap sedangkan mineral tertinggal pada bahan abon sehingga kadar abu lebih tinggi dibandingkan metode pan frying yang hanya menggunakan sedikit minyak.

Standar mutu abon sesuai SNI 01-3707-1995, mempersyaratkan kadar abu maksimal adalah 7\%. Dapat diketahui pada Tabel 1, pada metode pan frying untuk semua konsentrasi jamur tiram memiliki kadar abu yang memenuhi persyaratan. Pada metode deep frying hanya konsentrasi jamur tiram $15 \%$ saja yang memenuhi standar mutu. Sedangkan pada konsentrasi $30 \%$ dan $45 \%$ kadar abu lebih dari $7 \%$. Hal ini disebabkan penguapan kadar air yang lebih besar pada kedua konsentrasi tersebut mengakibatkan jumlah mineral pada bahan akan meningkat pula. Menurut Andarwulan et al. (2011), pengaruh pengolahan pada bahan dapat mempengaruhi ketersediaan mineral bagi tubuh.

\section{Kadar Protein}

Protein merupakan molekul makro yang mempunyai berat molekul antara 5000 hingga beberapa juta. Protein terdiri atas rantai-rantai panjang asam amino, yang terikat satu sama lain dalam ikatan peptida. Unsur nitrogen adalah unsur utama protein karena terdapat di dalam semua protein yang memiliki proporsi $16 \%$ dari total protein (Almeitser, 2009).

Hasil analisis kadar protein abon udang berkisar antara $12,51 \%$ sampai dengan $24,29 \%$. Hasil analisis sidik ragam menunjukkan bahwa metode pengorengan ( frying) berpengaruh nyata terhadap kadar protein abon udang Panaeus indicus sedangkan konsentrasi jamur tiram tidak berpengaruh nyata. Pada Tabel 1 , terlihat nilai kadar protein pada abon udang yang diproses dengan metode pan frying (20,36 - 24,29\%) lebih besar dibandingkan metode deep frying $(12,51-17,98 \%)$. Pada metode deep frying dilakukan penambahan minyak goreng sebagai media penghantar panas. Minyak goreng terabsorpsi pada bagian dalam bahan udang maupun jamur tiram (mengisi pori-pori) menyebabkan terjadinya perubahan tekstur, warna dan cita rasa dari abon udang. Adanya transfer panas melalui konduksi pada bagian dalam udang maupun jamur tiram mengakibatkan protein mengalami kerusakan (koagulasi). Kenaikan suhu pada metode deep frying lebih tinggi dibandingkan dengan metode pan frying. Hal ini menyebabkan kadar protein abon udang dengan metode pan frying lebih tinggi. Menurut Ketaren (2008) metode penggorengan dapat mengubah mutu makanan dan memberikan efek akibat destruksi termal mikroorganisme dan enzim; mengurangi kadar air sehingga daya simpan menjadi lebih baik.

Selain itu selama proses pengolahan abon udang terjadi proses pemanasan yang berulang yaitu proses penyangraian pada udang dan proses pengukusan pada jamur tiram putih, serta proses penggorengan pada tahap akhir proses. Proses pemanasan yang berulang ini mengakibatkan terjadinya denaturasi protein. Semakin lama proses pemanasan mengakibatkan kadar protein bahan semakin menurun. Menurut Sultoniyah et al (2013), pengolahan bahan pangan berprotein yang tidak dikontrol dengan baik dapat menyebabkan terjadinya penurunan nilai gizinya. Pada metode deep frying, penggunaan minyak sebagai media penghantar panas mengakibatkan suhu penggorengan lebih tinggi dan panas lebih merata dibandingkan metode pan frying. Hal ini menghasilkan abon dengan kadar protein lebih rendah dibandingkan metode pan frying. Seperti dilaporkan oleh Anggorowati et al (2012) yang menyebutkan bahwa lama waktu penggorengan sangat berpengaruh terhadap kandungan protein dari abon nangka muda.

Berdasarkan SNI 01-3707-1995, persyaratan standar mutu abon secara umum nilai kadar protein minimal adalah $15 \%$. Pada tabel 1 dapat dilihat hampir semua perlakuan konsentrasi memenuhi persyaratan standar mutu abon, kecuali pada konsentrasi $45 \%$ metode deep frying. Selain disebabkan proses pengolahan dengan panas yang berulang dan pada proses penggorengan dengan komposisi udang dan jamur tiram yang hampir sama. Dimana 
kadar protein jamur tiram putih lebih kecil dibandingkan udang. Hal ini mengakibatkan kadar protein abon pada konsentrasi $45 \%$ metode deep frying ini paling rendah. Pada proses penggorengan terjadi reaksi maillard yang menghasilkan perubahan sifat sensorik produk abon. Menurut Prangdimurti (2007) reaksi maillard dalam makanan dapat berfungsi untuk menghasilkan sifat sensorik pangan seperti flavor dan aroma. Pada beberapa produk pangan dapat memberikan pengaruh yang tidak dikehendaki, seperti dapat menurunkan kadar kelaruran protein. Sedangkan Muliawati dkk (2016) melaporkan interaksi suhu dan waktu penggorengan memberikan pengaruh nyata terhadap sifat organoleptik abon ikan tuna (Euthynnus affinis).

\section{Kadar Lemak}

Lemak terdapat pada hampir semua bahan pangan dengan kandungan yang berbedabeda (Winarno, 2002). Lemak terdiri dari trigliserida campuran yang merupakan ester dari gliserol dan asam lemak rantai panjang. Lemak jika dihirdolisis akan menghasilkan 3 molekul asam lemak rantai panjang dan satu molekul gliserol (Ketaren, 2008)

Hasil uji kadar lemak abon udang pada penelitian ini berkisar antara 3,3\% sampai dengan $14,03 \%$. Hasil analisis sidik ragam menunjukkan konsentrasi jamur tiram tidak berpengaruh terhadap kadar lemak abon udang Panaeus indicus. Pada tabel 1 dapat diketahui kadar lemak abon udang pada metode deep frying lebih tinggi daripada metode pan frying. Proses pengunaan minyak yang banyak pada metode deep frying menyebabkan minyak diserap oleh bahan abon. Hal ini mengakibatkan kadar lemaknya jauh lebih tinggi dibandingakan metode pan frying yang hanya menggunakan sedikit minyak saja. Menurut Muchtadi dan Ayustiningwarno (2010), metode deep frying adalah proses penggorengan dengan menggunakan minyak goreng yang banyak sehingga bahan pangan yang digoreng akan terendam seluruhnya didalam minyak goreng tersebut. Suhu penggorengan deep frying biasanya menggunakan suhu $170-200^{\circ} \mathrm{C}$.

Sesuai standar mutu abon SNI 01-3707-1995, nilai kadar lemak maksimal 30\%, sedangkan nilai kadar lemak tertinggi pada produk abon udang ini sebesar $14,03 \%$ pada kosentrasi jamur tiram 30\% metode deep frying. Hal ini menunjukkan nilai kadar lemak pada semua perlakuan memenuhi persyaratan standar mutu abon.

\section{Serat}

Serat kasar adalah zat sisa asal tanaman yang biasa dimakan yang masih tertinggal setelah bertutut-turut diekstraksi dengan zat pelarut, asam encer dan alkali. Dengan demikian nilai zat serat kasar selalu lebih rendah dari serat pangan, kurang lebih hanya seperlima dari seluruh nilai serat pangan. Hasil analisis serat kasar abon udang pada penelitian ini berkisar antara 4,53\% sampai dengan 12,83\%. Hasil analisis sidik ragam menunjukkan pengaruh konsentrasi jamur tiram terhadap kadar serat abon udang Panaeus indicus. Semakin tinggi konsentrasi jamur tiram yang ditambahkan kadar serat baon udang juga semakin tinggi. Tingginya kadar serat pada abon udang dengan bahan pengisi jamur tiram putih, dikarenakan jamur tiram putih segar memiliki kandungan serat yang lebih tinggi pula yaitu $11,5 \%$. Berdasarkan persyaratan standar mutu abon sesuai SNI 01-3707-1995, nilai kadar serat kasar maksimal 1,04\%, dan nilai kadar serat kasar tertinggi pada produk abon udang ini sebesar $10,49 \%$ berada diatas persyaratan standar mutu abon. SNI 01-3707-1995

\section{Analisis Mikrobiologi}

Hasil analisis mikrobiologi berupa angka lempeng total (ALT), dan Salmonella pada abon udang Panaeus indicus seperti ditampilkan pada Tabel 2. 
Tabel 2. Rerata nilai uji mikrobiologi abon udang (Panaeus indicus) dengan konsentrasi jamur tiram dan metode pengorengan yang berbeda

\begin{tabular}{c|c|c|c}
\hline \multirow{2}{*}{ Metode Pengolahan } & \multicolumn{2}{|c|}{$\begin{array}{c}\text { Konsentrasi Jamur } \\
\text { Tiram }\end{array}$} & \multicolumn{2}{c}{$\begin{array}{c}\text { Salmonella } \\
\text { (koloni/25g) }\end{array}$} \\
\hline \multirow{3}{*}{ Pan Frying } & $15 \%$ & $1,22 \times 10^{3}$ & Negatif \\
\cline { 2 - 4 } & $30 \%$ & $1,29 \times 10^{3}$ & Negatif \\
\cline { 2 - 4 } & $45 \%$ & $5,97 \times 10^{2}$ & Negatif \\
\hline \multirow{3}{*}{ Deep Frying } & $15 \%$ & $3,98 \times 10^{4}$ & Negatif \\
\cline { 2 - 4 } & $30 \%$ & $3,67 \times 10^{3}$ & Negatif \\
\cline { 2 - 3 } & $45 \%$ & $1,98 \times 10^{3}$ & Negatif \\
\hline \multicolumn{2}{c}{ SNI 01-3707-1995 } & $5 \times 10^{4}$ & Negatif \\
\hline
\end{tabular}

Menurut Fardiaz (1992), cemaran mikroba pada makanan dapat terjadi selama pemanenan, penanganan atau selama pengumpulan dan pengolahan. Hasil analisis mikrobiologi abon udang untuk parameter Salmonella baik pada konsentrasi jamur tiram maupun pada metode penggorengan adalah negatif, sesuai persyaratan standar mutu abon SNI 01-3707-1995. Sementara parameter Angka Lempeng Total menunjukkan abon udang memiliki nilai ALT dibawah persyaratan mutu yang ditetapkan yaitu 5,00 x 104. Walaupun nilai ALT masih dibawah standar akan tetapi dengan kadar air yang cukup tinggi, sangat berpengaruh terhadap masa simpan produk. Hasil pengamatan secara visual, abon udang ini memiliki masa simpan kurang lebih 14 hari, lebih lama dibandingkan masa simpan abon udang yang diproduksi oleh IKM yang hanya bertahan sampai tiga hari.

\section{KESIMPULAN}

Metode penggorengan memberikan pengaruh nyata terhadap kadar abu, protein dan kadar lemak, sedangkan konsentrasi jamur tiram putih yang berbeda berpengaruh nyata pada kadar air dan kadar serat abon udang Panaeus indicus.

Abon udang Panaeus indicus memiliki kadar air 31,59-46,9\%, kadar abu 4,55 - 7,92\%, kadar protein 12,51 - 24,29\%, kadar lemak 3,3-14,03\%, serat kasar 4,53-12,83\%,

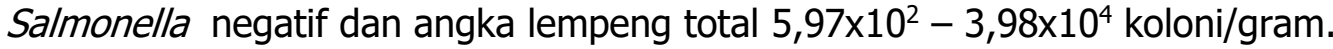

\section{UCAPAN TERIMAKASIH}

Terimakasih kepada Balai Riset dan Standardisasi Industri Samarinda yang telah mendanai kegiatan penelitian dan IKM - Kaya Rasa yang telah bekerjasama dalam upaya meningkatkan mutu produk hasil perikanan yang dihasilkan.

\section{DAFTAR PUSTAKA}

Almeitser, S., 2009. Prinsip Dasar Ilmu Gizi. PT. Gramedia Pustaka Utama. Jakarta.

Andarwulan,N., F. Kusnandar, D. Herawati. 2011. Analisis Pangan. Dian Rakyat. Jakarta.

Anggorowati, D.A., Setyawati, H., panawar Purba, A.B.. 2012. Peningkatan Kandungan protein Abon Nangka Muda. Jurnal Teknik Kimia Vol.7 No.1. (17-21)

Badan Standardisasi Nasional. 1995. SNI 01-3707-1995: Abon. Badan Standardisasi Nasional. Jakarta. 
Badan Standardisasi Nasional. 2006. SNI 01-2332-2006: Pengujian Ikan dan Produk Perikanan. Badan Standardisai Nasional. Jakarta.

Buckle, K.A., Edwards, R.A., Fleet, G.H. and Wootton,M. 2009. Ilmu Pangan. UI Press. Jakarta

Dewi, E.N., Parmawati, M dan Ibrahim R. 2012. Kualitas Abon Ikan Tongkol (Euthynnus affinis

Cantor) yang Diproses Secara Deep Frying dan Pan Frying Selama Penyimpanan Pada

Suhu Kamar. Prosiding Semnas Hasil-hasil Penelitian Perikanan dan Kelautan. FPIK Universitas Diponegoro Semarang. Vol.1. Hal.: 52-58

Dewi, R.A., 2011. Sifat Organoleptik Abon Ikan Substitusi Jantung Pisang. Program Studi Tata

Boga. Fakultas Teknik. Universitas Negeri Malang. Malang.

Fachrudin, L., 1997. Teknologi Tepat Guna Membuat Aneka Dendeng. Kanisius. Yogyakarta.

Fardiaz, S. 1992. Mikrobiologi Pangan. Gramedia Pustaka Utama, Jakarta

Fennema, O.R. 1996. Food Chemstry. Marcel Decker Inc. New York.

Jamilah N. 2016. Kandungan Karbohidrat dan Protein Jamur Tiram Putih (Pleurotus ostreatus)

pada Media Tanam Serbuk Kayu Kemiri (Alleurites moluccana) dan Serbuk Kayu

Campuran. Jurnal Eksakta. Volume 1.

Ketaren.S., 2008. Pengantar Teknologi Minyak dan Lemak Pangan. UI Press. Jakarta

Muliawati, M., Mus, S dan Buchari,D., 2016. The effect of the temperature and frying time

on the quality of spice shredded Fish of little tuna (euthynnus affinis). JOM

Muchtadi, T. R dan Ayustaningwarno, F. 2010. Teknologi Proses Pengolahan Pangan. Alfa Beta. Bandung.

Nazir, M., 2005. Metode Penelitian. Ghalia Indonesia. Bogor.

Novrihansa R., Rahman Karnila dan Suparmi. Pengaruh Penambahan Konsentrasi Garam Berbeda Selama Perebusan Terhadap Kandungan Kolesterol Udang Putih (Penaeus indicus ). https://media.neliti.com/media/publications/. Diakses pada 13 Desember 2018

Prangdimurti, E., F. R. Zakaria, Dan N. S. Palupi. 2007. Modul E-Learning Evaluasi Nilai Gizi Biologis Pangan. Departemen Ilmu Dan Teknologi Pangan. Bogor: Fakultas Teknologi Pertanian IPB.

Sudarmadji. S., Haryono, B., Suhardi. 1997. Analisa Bahan Makanan dan Pertanian. Liberty Yogyakarta. Yogyakarta.

Suryani, A., Hambali, E., dan Hidayat, E. 2007. Membuat Aneka Abon. Penerbit Penebar Swadaya. Jakarta.

Susanty, A., Purwanti., Kurniawaty dan Dewi,A. 2016. Pengaruh Penambahan Bahan Pengisi Terhadap Kualitas Abon Udang. Laporan Penelitian Balai Riset dan Standardisasi Industri Samarinda.

Susanty, A. 2016. Pengaruh Penambahan Bahan Pengisi Terhadap Karakteristik Fisikokimia, Mikrobiologi dan Sensoris Abon Udang (Panaeus indicus). Jurnal Riset Teknologi Industri Vol. 10 No.2 DOI: http://dx.doi.org/10.26578/jrti.v10i2.2567

Tato, A., Sukmiwati, M., Sari, I., 2014. Studi Penerimaan Konsumen Terhadap Abon Nila (Oreochromis niloticus) dengan Penambahan Jamur Tiram Putih (Pleurotus ostreatus). Jurnal Perikanan dan Kelautan Volume 19 Nomor 1. ISSN 0853-7607. Jakarta.

Widyastuti, N., Tjokrokusumo.D., Giarni, R. 2015. Pasca Panen Jamur Tiram Putih (Pleurotus Sp.) Dengan Teknik Pengeringan Oven. Prosidng Seminar Nasional Masyarakat Biodiversity Indonesia. Vol 1 No.7: 1693-1697 DOI: 10.13057/psnmbi/m010729

Winarno, F.G. 2002. Kimia Pangan dan Gizi. PT Gramedia Pustaka Utama. Jakarta

Zhang, Q., A.S.M. Saleh, J. Chen, Q. Shen. 2012. Chemical alterations taken place during deepfat frying based on certain reaction products: A review. Chemistry and Physics of Lipids, 165: $662-681$. 